\title{
Is this what the world's coming to?
}

\begin{abstract}
With climate change placing increasing pressure on environmental resources, it is now being viewed as a threat to national security. Amanda Leigh Haag reports.
\end{abstract}

History is littered with lessons from once-budding civilizations that crashed from their peak of prosperity. From the Anasazi of the southwestern United States to the Mayans of Mesoamerica ${ }^{1}$ and the ancient dynasties of eastern China ${ }^{2}$, environmental change has sounded the death knell throughout time for oncethriving civilizations already stressed by factors including high population growth, overexploitation of resources and excessive reliance on external trade. In many cases, severe drought or extreme cold has been enough to push societies to the brink of civil unrest, mass migration and warfare.

But it's not necessary to look that far back into history to see how environmental change can result in conflict and the breakdown of society. In a study published in a special issue of the journal Political Geography ${ }^{3}$, titled Climate Change-induced Migration and Violent Conflict, Rafael Reuveny, a political scientist at Indiana University, found that, of 38 cases of migration directly attributable to climate change during the twentieth century, half led to conflict, some of which were violent. And existing conflicts, such as that in Darfur ${ }^{4}$, are already being worsened by the impacts of global warming. Plagued by drought for more than three decades, Lake Chad - once one of the largest freshwater sources in Africa on which 20 million people depend - has shrunk to $5 \%$ of its original volume, with competition over water and land exacerbating other tensions ${ }^{5}$.

\section{People are now recognizing that it's not just happening in some distant African country but that the effects could be on your own doorstep.}

Zafar Adeel

\section{UNPARALLELED IMPACTS}

With similar scenarios seeming increasingly likely in the future, climate change is now being viewed as a threat to

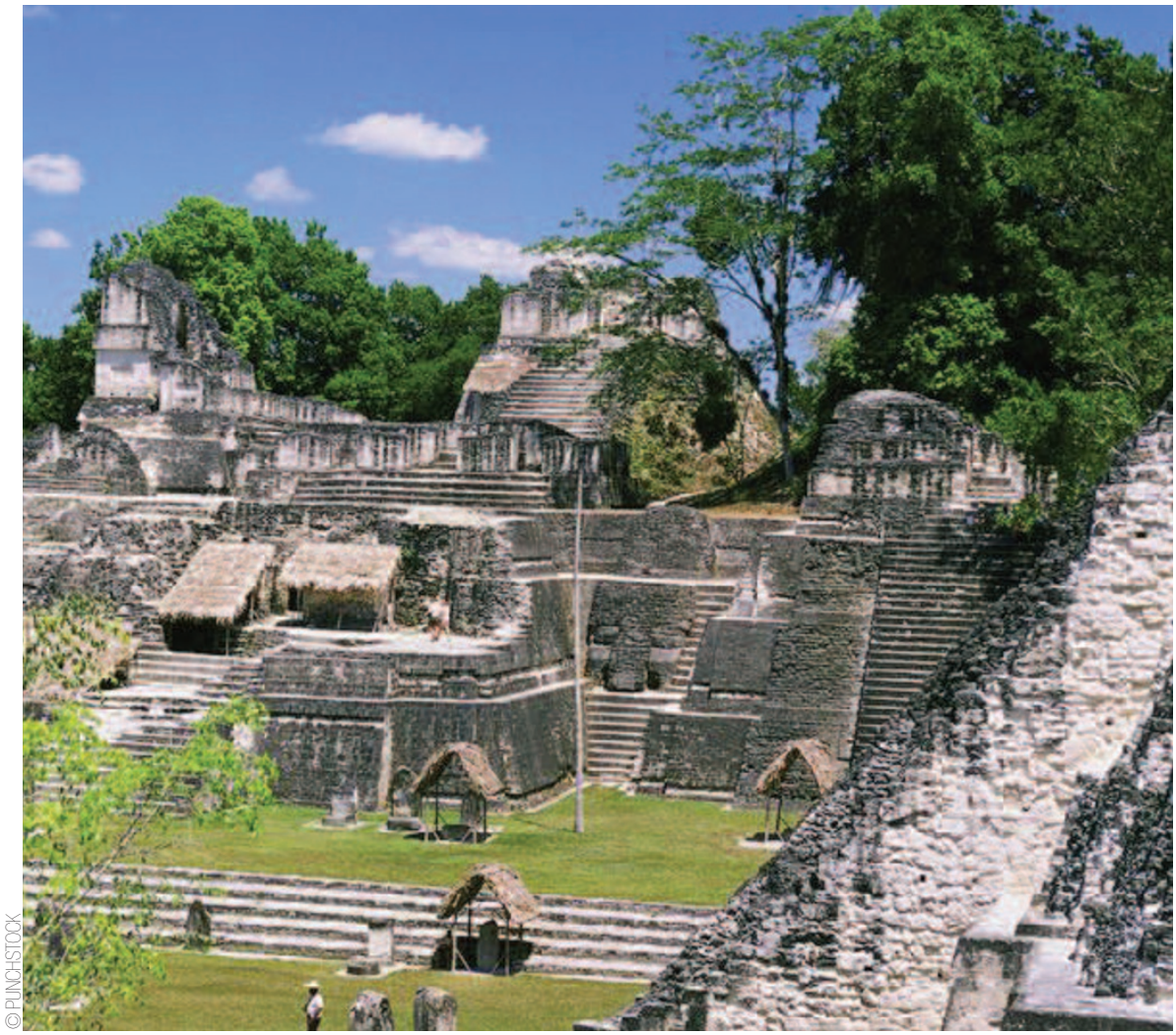

Environmental change is believed to have been a factor in the collapse of the Mayan civilisation of MesoAmerica.

human security. Unlike the many examples throughout history, the potential globalscale effects of environmental change in the coming decades are unprecedented. No one is certain how these changes will manifest themselves in human populations, but it is becoming a matter of growing speculation among government leaders, policymakers and scientists. A number of countries, including the US, the UK and Germany, are analysing the security risks of climate change, and the US is considering legislation to produce a national intelligence estimate to assess the dangers.

Recent projections of the Intergovernmental Panel on Climate Change (IPCC) estimate that by 2080, 1.1 billion to 3.2 billion people will be facing water scarcity; 200 million to 600 million, hunger; and two million to seven million more homes will be hit hard by coastal flooding ${ }^{6}$. Between 75 and 250 million people in Africa alone will experience increased water shortages due to climate change by 2020. Although greater wealth may offset damage through adaptation in many nations ${ }^{7}$, without the ability to pay for such measures the world's poor are likely to suffer more stress from climate impacts in the coming decades. Even more worryingly, many of the seemingly dire predictions are based on middle-of-theroad IPCC scenarios, rather than the most extreme ones, says Jay Gulledge, a climate scientist with the Washington DC-based Pew Center on Global Climate Change. "Many of these conditions are already being observed," Gulledge says. "You don't have to stretch much to get some pretty bad consequences in the coming decades just from the changes in freshwater availability." 


\section{BISING TENSIONS}

In countries such as Algeria, Morocco, the United States, France, Spain and Italy, migration is now an issue of increasing political importance, according to a recent report by the $\mathrm{UN}^{8}$. The report noted that around 50 million people will be at risk of displacement due to severe desertification over the next 10 years, causing an "environmental crisis of global proportions". These risks threaten not just unstable regions, but also countries that are likely to experience the spillover of large-scale migration from areas directly impacted by a changing climate. "People are now recognizing that it's not just happening in some distant African country but that the effects could be on your own doorstep," says Zafar Adeel, a policy expert at the United Nations University in Hamilton, Canada, and a lead author of the report.

\section{Migration as an adaptation option is missing the point. Adaptation should aim to protect the rights of people to live in their home.}

\section{Jon Barnett}

Accordingly, issues of border security are gaining increasing attention, with the realization that heightened regional flooding or drought will probably result in an upsurge in immigration. Spain is involved in ongoing discussions with northern African nations to find possible preventive measures to large-scale immigration. "There's a notion that by investing in North African countries, it would be possible to create more amenable conditions so that people don't have to move north," says Adeel. But, he says, the reality is that North African countries are already having their resources stressed due to immigration from sub-Saharan Africa. Along with considerations about potential adaptation strategies, these regions are also facing looming pressures to reinforce their border control in order to stem the flow of large numbers of immigrants. "If you get into extreme climate change, there may be no easy way to manage the flow of people who are coming at you from every possible direction," says Leon Fuerth, a professor of international affairs at George Washington University in Washington DC.

Similarly, India looks set to face these issues as rising sea levels could result in the mass-migration of millions from Bangladesh over the next century. Since the 1950 s, some 12 to 17 million
Bangladeshis have migrated to India, according to Reuveny, due in large part to natural disasters, droughts and food scarcity. Half of Bangladesh is situated just a few metres above sea level and about a third of the country is flooded during the rainy season. Bangladesh faces the future loss of large areas of coastline due to flooding and sea-level rise, which could affect 35 million people, or a quarter of its population ${ }^{8}$. Tensions are already high, as the 4,000-kilometre, 3-metrehigh barrier that India has spent nearly a decade erecting along the border is due for completion this year. And along the US-Mexico border, political tensions over water and agricultural resources are bound to escalate as temperatures rise. The IPCC projects that the southwestern US and parts of northern Mexico will become more arid and could experience a decline in water availability of $10-30 \%$ by the end of the century. By the 2050s, 50\% of agricultural lands in Latin America are very likely to undergo desertification and salinization. "If agricultural productivity in Mexico declines, we're going to see even greater pressure," says US defense and energy consultant Thomas Morehouse.

\section{EXIT STRATEGIES}

Regions likely to bear the brunt of climate impacts are already beginning to look to neighbouring states for potential resettlement. According to IPCC projections, global average sea level will rise between $18-59$ centimetres by 2100 , but some estimates ${ }^{10}$ say that could be as much as 1.4 metres. Future evacuation is probable for some low-lying Pacific islands vulnerable to sea-level rise and extremeweather intensity. In recent years, they have initiated discussions with their neighbours Australia and New Zealand about possible safe migration routes to nearby countries on higher ground. The government of Tuvalu, a Polynesian island nation with a population of some 12,000, negotiated an agreement with New Zealand to accept 75 Tuvaluan immigrants annually, a program that began in 2002. So far Australia has not agreed to a similar resettlement deal. Yet despite the potential exit strategies, some believe that the focus should be on securing the sovereignty and the rights of societies that will be impacted by climate change. "Migration from the Pacific and from small-island states as an adaptation option is missing the point," says Jon Barnett, a political geographer at the University of Melbourne, Australia. "Adaptation should aim to protect the rights of people to live in their home."

As certain regions increasingly face such demands from their neighbours, longstanding alliances may weaken, warns Morehouse. "As immigration increases, Europe is inevitably going to become more inwardly focused and less inclined to devote resources to the kind of partnerships that we might look to them for to ensure broader international security," he says. Under future IPCC scenarios, the Mediterranean region will experience reduced annual precipitation. "You're going to have a southern Europe that is baking every summer and unable to grow crops," Gulledge notes. "People will be migrating into central Europe through southern

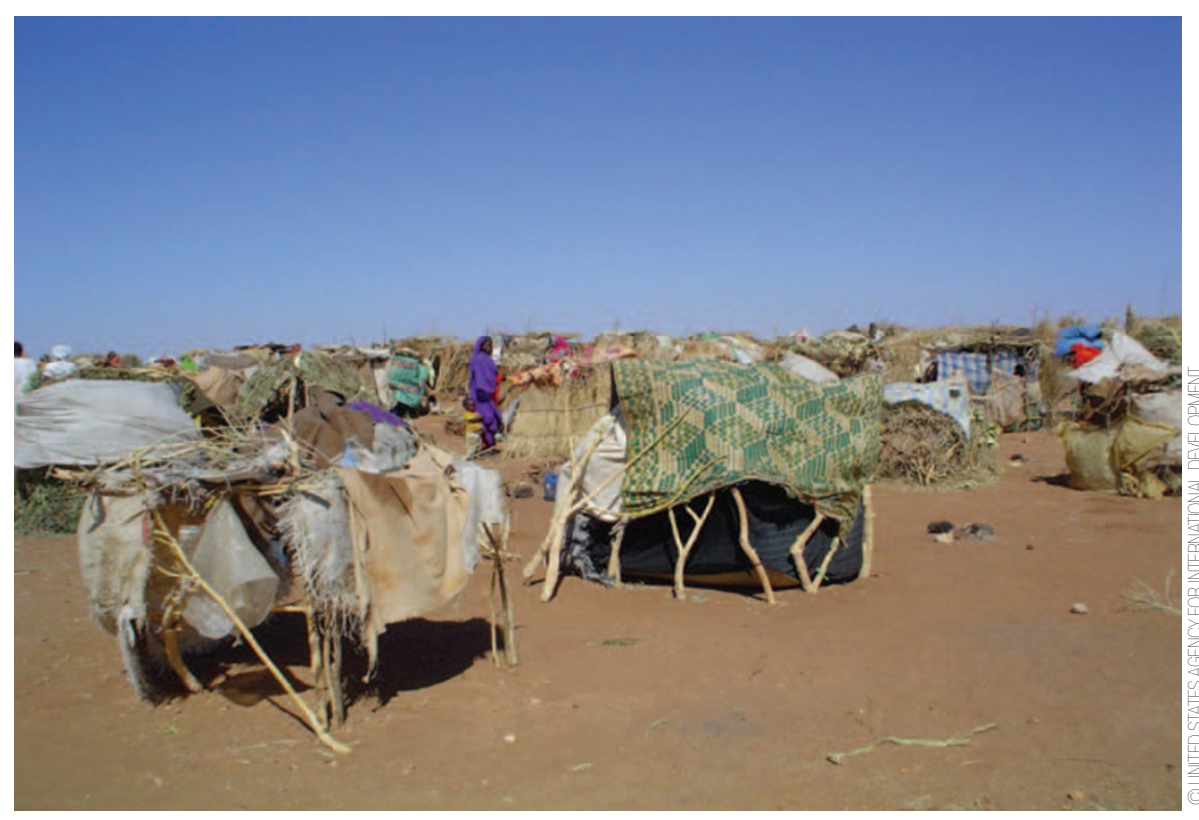

Existing conflicts, such as that in Darfur, are already being worsened by the impacts of global warming. 
Europe, and the EU is going to struggle with keeping its member states together as they disagree on immigration policy."

Although it is impossible to predict social and political consequences based on a broad range of potential climatechange outcomes, a few experts are now beginning to imagine and examine some of the worst-case scenarios. Fuerth, who spent 30 years as a foreign-affairs analyst, including eight years as Vice President Al Gore's national-security advisor in the White House, has studied and projected possible social implications of severe climate change over a 30-year period, based on the potential for 'nonlinear' climate change and 'tipping points' such as the abrupt release of methane from thawing Arctic tundra. Emphasizing that such exercises should never be interpreted as forecasts, but as scenarios designed to promote rigorous thinking, he says that nonlinear environmental change could give rise to nonlinear societal change. One outcome of increasing pressure on borders and natural resources could be a kind of international class warfare, says Fuerth, as wealthier nations shore up their borders against waves of environmental refugees. "Whenever fear takes over or is helped along by political leadership, it can result in very severe measures aimed against some set of people who are deemed a threat," Fuerth says. For instance, Fuerth believes that tensions could become high even between partners such as the US and Canada owing to clashes over fishing rights and waterway navigation.

\section{We will pay to reduce}

\section{greenhouse gas emissions}

today... or we will pay the price later in military terms. And that will involve human lives.

General Anthony C. Zinni.

\section{MILITARY MEASURES}

With serious impacts of climate change appearing increasingly imminent, a handful of nations are now taking a closer look at the role of the military in preparing for national-security threats. In April, the CNA Corporation, a non-profit US think tank released a report titled National Security and the Threat of Climate Change ${ }^{11}$, which was overseen by a decorated military advisory panel and concluded that "projected climate change will seriously exacerbate already marginal living standards in many Asian, African and Middle Eastern nations, causing widespread

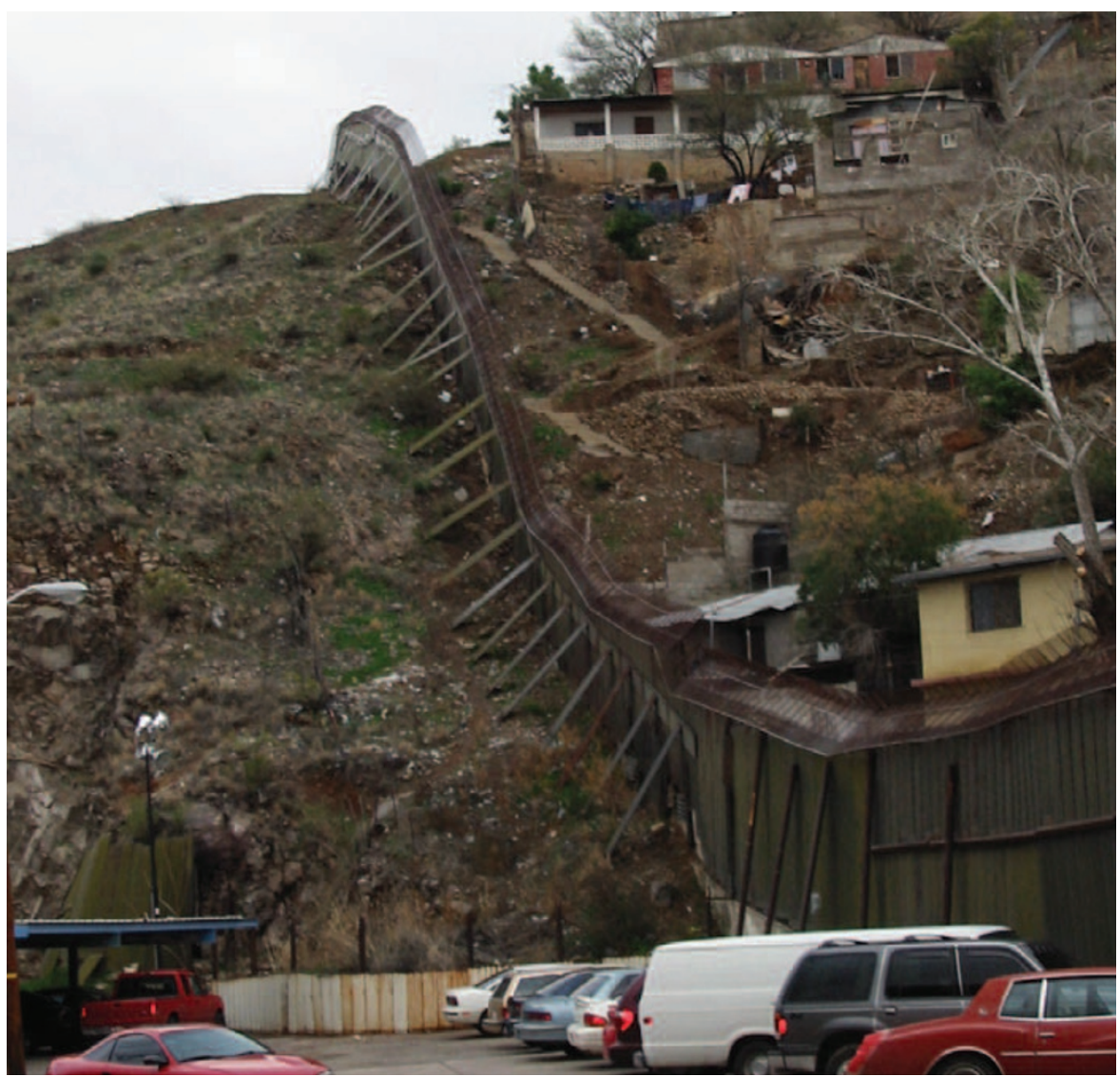

Along the US-Mexico border, political tensions over water and agricultural resources are bound to escalate as temperatures rise.

political instability and the likelihood of failed states". General Anthony C. Zinni, former commander-in-chief of US Central Command stated, "We will pay to reduce greenhouse gas emissions today...or we will pay the price later in military terms. And that will involve human lives."

It's clear that heading off the worst-case scenarios will require an enormous global effort. As was the case in the 2004 Indian-Ocean tsunami that killed some 300,000 people, the more extreme military scenarios would require large-scale deployment of troops and emergency aid. Joshua Busby, an assistant professor of public affairs at the University of Texas, Austin, says that by taking earlier preventive measures, putting early-warning systems in place, and working with relief organizations well in advance, problems can be stemmed before "thousands are starving and living in camps on borders between countries and we are having to make up for previous policy failures".

According to Kurt Campbell, CEO of the Center for a New American Security, a US-based national security think tank, "Confronting climate change will be this generation's Cold War, only much more difficult because it could literally undermine the very notion of societal stability. Certain aspects of civilization will come under enormous stress and hardship." And Reuveny maintains that small-scale adaptation efforts are wholly insufficient for dealing with the potential security issues from climate change. "We are trying to do this by giving bits and pieces," he says. "This doesn't work. It has to be something of a Marshall plan," Reuveny says, referring to the US commitment to building up its European allies through large amounts of aid relief following the Second World War. "They were our allies and we needed them to be strong, so we helped them." Increasingly, high-level officials are recognizing that by failing to help regions that are most vulnerable to climate change, they may be increasing the likelihood of 'failed' states and the threats they will pose to more stable, developed nations.

\section{AVERTING DISASTER}

So far, no comprehensive cost estimates exist for the type of global-scale military preparedness that would be needed under severe climate-change scenarios. Yet it appears that, irrespective of conflict and the potential for national-security threats, the goals of assisting vulnerable nations 
and at-risk regions in the face of climate change are synonymous with the need to achieve global sustainable development. Citing East Timor in southeast Asia as an example, Barnett says "what you would do to reduce vulnerability and adapt to climate change is what you would do to provide sustainable development and improve the lives of people anyway". With the majority of the population having no access to electricity, clean drinking water, shelter or proper food standards, he notes that many of these basic services could be fulfilled through the commitment made by wealthy countries under the Rio Declaration on Environment and Development in 1992. Developed countries vowed long ago to giving $0.7 \%$ of their gross domestic product to aid developing countries, but actual contributions fall far short of that, with donations from both the US and Australia hovering around $0.2 \%$, for instance. "For the most part, we're talking about things that we already know how to do, things we already know we should do, things that we've already committed to do, it's just that we don't do them", says Barnett.

However, Fuerth points out that in the case of extreme climate-change outcomes, more radical measures might be needed. He cites examples such as the potential development of superior materials through nanotechnology and suggestions for planetary 'geoengineering', such as erecting mirrors in space to reflect sunlight. There seems to be a "philosophical split" between those who believe that the system can be rebalanced through proper adaptation and mitigation versus those inclined to approach the solution as a "civil-engineering problem on a cosmic scale", Fuerth says. "If it becomes clear that we are headed toward the severe end of the range, then those who have these bigger schemes in mind may get a much more serious hearing."
Amanda Leigh Haag is a freelance writer based in Denver, Colorado.

\section{REFERENCES}

1. Diamond, J. Collapse: How Societies Choose to Fail or Succeed (Viking Adult, New York, 2005)

2. Zhang, D. D., Zhang, J., Lee, H. F. \& He, Y.-Q. Hum. Ecol. 35, 403-414 (2007).

3. Reuveny, R. Polit. Geogr. 26, 656-673, (2007).

4. Available via http://tinyurl.com/24nzrk.

5. <http://sudanreport.unep.ch/chapters/04_conflict.pdf >, page 77, section 4.3 .

6. Climate Change 2007: Climate Change Impacts, Adaptation and Vulnerability; <http://www.ipcc.ch/SPM13apr07.pdf>.

7. Lomborg, B. Cool It: The Skeptical Environmentalist's Guide to Global Warming (Knopf, New York, 2007).

8. Adeel, Z. et al. Overcoming one of the Greatest Environmental Challenges of our Times: Re-thinking Policies to Cope with Desertification (Algiers, Algeria, 2006); <http://allafrica.com/ sustainable/resources/view/00011169.pdf>

9. Stern Review on the Economics of Climate Change (HM Treasury, London, 2006); available via $<$ http://tinyurl. com/ye5to7>.

10. Rahmstorf, S. Science 315, 368 (2007)

11. National Security and the Threat of Climate Change (CNA Corporation, Virginia, 2007); <http://securityandclimate.cna org/report/>

\section{nature} REPORTS avian $\mathrm{Au}$

the news behind the science, the science behind the news
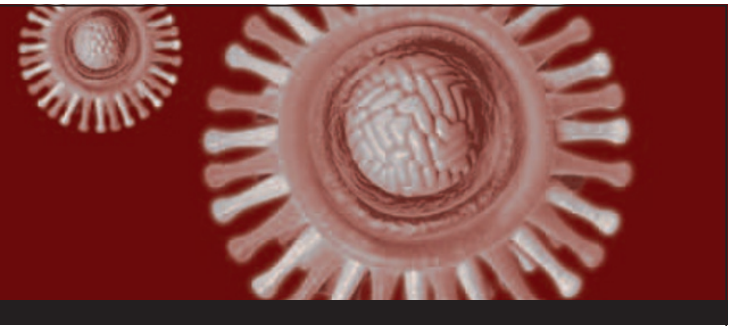

Looking for avian flu research and latest news?

Add this link to your favourites: www.nature.com/reports/avianflu

Nature Publishing Group has now assembled all of its articles, reports, commentary and news stories on avian flu and the H5N1 virus in one website.

Continually updated with any new material published, and with much of the content free access, Nature Reports Avian Flu is all you need to stay connected to the science behind the news on this potential pandemic.

www.nature.com/reports/avianflu
Plus:

- Join the discussion in the avian flu blog

- Downloadable free quarterly digital edition

- Top frequently asked questions on avian flu

- Avian flu timeline

- Monthly emailed newsletter

- Google Earth map showing spread of the disease

Produced with support from:

an unrestricted educational grant from

GlaxoSmithKline Biologicals (Principal Sponsor) and Gilead Sciences (Supporting Sponsor) 